\title{
Iconografía del Rock en el formato LP (1956 - 1982)
}

\author{
Eduardo Rodríguez Clavo \\ Universidad Complutense de Madrid. Facultad de Geografía e Historia. \\ Departamento de Historia del Arte III (Contemporáneo)
}

\begin{abstract}
RESUMEN
Un recorrido audiovisual a través de los primeros veinticinco años de un fenómeno que trasciende lo estrictamente musical -el Rock-; los diferentes subgéneros que se han ido sucediendo y la emanaciones iconográficas que esos periodos han generado. El ámbito del análisis queda circunscrito a un formato concreto: el disco de larga duración (LP), utilizado desde la irrupción de Elvis Presley, en 1956, hasta el advenimiento del disco compacto (CD) en 1982.
\end{abstract}

Palabras clave: Iconografía; Rock; Portadas de discos; Formato LP.

\section{Rock Iconography in the LP format (1956 - 1982)}

\begin{abstract}
An audio-visual journey through the first twenty five years of Rock, going beyond of strictly musical aspects. The different minor genres across the decades and the iconographic emanations generated in these periods. This analysis is related directly to an specific format: the Long Play record (LP), from Elvis Presley, in 1956, up to the advent of Compact Disc (CD), in 1982.
\end{abstract}

Keywords: Iconography; Rock; Record covers; LP Format.

\section{Introducción}

Es la intención de esta exposición mostrar de forma sucinta algunas de las emanaciones iconográficas que un fenómeno de raíz musical como el Rock ha sido capaz de generar durante los primeros veinticinco años de su existencia; el periodo comprendido entre los años centrales de la década de los cincuenta y los primeros años ochenta del pasado siglo XX. El cúmulo de imágenes se presenta como un campo asilvestrado, pleno de contaminaciones y ruido que pocos estudiosos se han atrevido a desbrozar, porque ¿pertenecen algunas de esas representaciones icónicas al ámbito del arte? ¿Son merecedoras de engrosar el corpus académico? ¿Tienen entidad para codearse con otros artefactos santificados por críticos eruditos? Son cuestiones que quedan en el aire y que quizá el tiempo y la perspectiva ayuden a responder en un futuro no muy lejano. 
En un entorno social eminentemente icónico -espectacular- como lo definió Guy Debord en su premonitorio texto La sociedad del espectáculo, de 1967, donde lo banal convive con lo emocionante y lo falso se erige en dogma de fe para incautos, es labor enrevesada separar el grano de la paja, auscultar el marasmo de imágenes para intentar extraer alguna esencia digna, elaborar algo cercano a una conclusión rigurosa. En relación al tema que nos ocupa el obligado primer paso es la delimitación cronológica: 1956-1982; un periodo concreto de la segunda mitad del siglo $\mathrm{XX}$ en el que se ha revelado una acotación estilística digna de estudio: el Rock ${ }^{1}$.

Una vez insertos en esa demarcación se pueden establecer varios segmentos de análisis que coinciden con aquellos momentos en los que esas constantes icónicas llegan a adquirir un sentido propio. Así el Rock \& Roll (1956-1960) conforma el primer apartado con la explosión de una tendencia musical nueva dirigida a un público/consumidor emergente: la juventud occidental, un sector de población (entre los 13 y los 18 años) dotado de entidad generacional y poder adquisitivo reciente. El impacto visual de los nuevos mitos del celuloide (Marlon Brando y James Dean) junto a la proyección multimedia de las estrellas del Rock \& Roll (sobremanera Elvis Presley) y la potente iconografía generada por ciertas subculturas (Hipsters y Beatniks, en Estados Unidos y Teddy Boys, en Inglaterra ${ }^{2}$ ), se aderezan entre una vorágine de productos de consumo que se exhiben a través de los medios de comunicación de masas y que se muestran irresistibles a la par que plásticos: automóviles, motocicletas, guitarras eléctricas, televisores, máquinas de discos, autocines, gasolineras y cómo no, los discos de vinilo con sus carátulas coloristas, plenas de novedades gráficas y rostros descarados.

El segundo de estos segmentos es rico y prolijo, los años sesenta (1962-1969) son, desde el punto de vista de la iconografía del Rock, los más proteicos. Un grupo como The Beatles es capaz de generar un variado catálogo de imágenes que son fiel reflejo de la capacidad multimedia de la denominada década prodigiosa. Toda su discografía merecería un estudio iconográfico completo y son dignas de análisis sus apariciones estelares y su manejo de los medios (prensa, radio, televisión), la selección de fotógrafos a su servicio (Robert Freeman, Dezo Hoffmann, Richard Avedon), además de su protagonismo en los largometrajes de Richard Lester; $A$ Hard Day's Night (1964) y Help (1965). En la estela de The Beatles es obligado referirse a otros fenómenos asociados, ya sea el desarrollo de la moda juvenil (Carnaby Street) y la efervescencia capital del "Swinging London", así como el impacto de los demás representantes del Beat Británico (The Rolling Stones, The Who, The Kinks), la psicodelia (Cream, Jimi Hendrix, en Inglaterra, o los representantes

1 Entendiendo como tal la acepción genérica de un estilo musical con entidad propia. A partir de ahí y como convención se define ROCK como un todo heterogéneo que estaría formado por una serie de subgéneros deudores de esa matriz principal: Rock \& Roll, Pop, Psicodelia, Rock Sinfónico, Glam Rock, Punk y New Wave).

Vid. Hebdige, D., Subcultura: el significado del estilo, Barcelona, Paidós, 2004. 
del Rock Ácido de California, Quicksilver Messenger Service, Jefferson Airplane, entre otros). Sin menospreciar la impronta fundamental de las drogas (marihuana y LSD) y su traslación gráfica en el trabajo de los diseñadores de pósters y portadas de discos: Rick Griffin, Victor Moscoso, Stanley “Mouse" Miller, en San Francisco o Hapshash \& The Coloured Coat y The Fool, en Londres. Y con Sgt. Peppers Lonely Hearts Club Band (1967) como paradigma de la implantación de un formato universal para el rock, tanto en lo estrictamente musical como en lo gráfico: el disco de larga duración, Long Play o LP, un nuevo escaparate icónico para el arte.

Durante los años setenta cabría distinguir cuatro momentos diferenciados: en primer lugar y como evolución de la psicodelia aparecería el Rock Sinfónico (1969-1975), proveedor de una retórica iconográfica propia a través de las portadas de Roger Dean (Yes), el colectivo Hipgnosis (Pink Floyd) o H.R. Giger (Emerson, Lake \& Palmer).

Por su parte, el Glam Rock (1972-1975) ejercería un contrapeso teórico a la complejidad técnica y temática del Rock Sinfónico ofreciendo una expresión mucho más estereotipada y con predominio de la imagen del artista como reclamo, con exceso de maquillaje, androginia, equívoco sexual y regreso a un primitivismo rítmico emparentado con los orígenes del Rock \& Roll de finales de los años cincuenta. Los retratos fotográficos de Mick Rock (Lou Reed) o Justin de Villeneuve (David Bowie) pueden servir como marco de referencia.

El Punk (1976-1978) estalla como cesura revolucionaria ante un modelo audiovisual decadente: el propio Rock. Una nueva iconografía asociada impregna sus representaciones gráficas: cut-ups, collage, cromatismo chirriante, tipografías anárquicas y un lema implícito, DIY (Do It Yourself - Hazlo tu mismo). Se podría destacar la obra de Jamie Reid con Sex Pistols como epítome de esa punkitud.

La New Wave (1979 - 1980) se presenta como asimilación comercial tras el exabrupto punk. El colorismo pop y el revival posmoderno crean una iconografía definida que se irá diluyendo en la multiplicidad de subgéneros que anuncian la nueva década: After Punk, New Romantics, Tecnopop, así como un potente "mainstream" que asimila el Rock (Prince, Madonna, Bruce Springsteen, U2) alentado por el poder omnímodo de las discográficas multinacionales y amplificado por nuevos medios totalizadores, globales e inevitables.

\section{Rock \& Roll (1956 - 1960)}

Después de la II Guerra Mundial y tras el establecimiento de la neta supremacía anglosajona, el bloque occidental (Estados Unidos y Europa) se sumerge en las apacibles aguas del bienestar económico. La estabilidad social posibilita el desarrollo de nuevas tendencias, gustos, hábitos y actividades. La música popular aparece como una más entre una serie de opciones de ocio y entretenimiento. Tanto en Estados Unidos como en Inglaterra se sigue una tradición de cantantes meló- 
dicos blancos denominados Crooners que con voces aterciopeladas entre arreglos orquestales pulcros amenizan las veladas de las ciudades industrializadas. Frank Sinatra, Dean Martin o Bing Crosby ofrecen arrullos inofensivos y ensoñaciones románticas para todos los públicos.

Por otro lado, desde las entrañas de una población segregada -los afroamericanos- emerge un modo propio de expresión musical: el Rythm \& Blues, que amplifica el lamento de las grandes masas que emigran desde las plantaciones sureñas hacia los centros urbanos del norte (Chicago, New York, Detroit).

Otro sector de población, en su mayoría emigrantes europeos de segunda o tercera generación, ofrece el desarrollo de un estilo autóctono; el Country \& Western, en el que se incluyen ritmos sincopados y bailables y armonías folklóricas continentales.

Hasta aquí los ingredientes básicos del cocktail músico-cultural: estabilidad social e incipiente capacidad económica de la juventud, el ocio como válvula de escape y el consumo alentado desde los medios. La música ejerce de elemento potenciador y los emergentes ídolos cinematográficos son los catalizadores de una pose icónica que cala en el subconsciente juvenil. Sólo falta un protagonista que encarne esa rebeldía huera y que sea capaz de iluminar el firmamento de la nueva música popular. Elvis Presley es el elegido, el mesías del Rock \& Roll.

Cuando el sábado 28 de enero de 1956 aparece Elvis cantando Heartbreak Hotel en el "Dorsey Brothers TV Show" se hacen realidad en un instante y para una audiencia millonaria todos esos tics que se venían gestando en los films de Marlon Brando y James Dean con la contagiosa conjunción de unos ritmos híbridos e irresistibles ( Blues, Rythm \& Blues, Gospel, Country \& Western) ${ }^{3}$.

El primer LP de Elvis (en realidad una recopilación de canciones lanzadas anteriormente en formato single) se situó en los escaparates de las tiendas norteamericanas en marzo de 1956. La portada (fig. 1) resulta paradigmática al mostrar una serie de caracteres que marcan el inicio de una nueva concepción iconográfica. La fotografía aquí es clave, una instantánea en blanco y negro captada en uno de sus conciertos en la que los reclamos visuales son el gesto (dislocado) y el movimiento (agitado). El ritmo sincopado que aporta el nuevo estilo queda patente en la composición descentrada del cantante interpretando con una guitarra acústica uno de los números de su repertorio. El extremo de la guitarra, donde se sitúa el clavijero, aparece movido con un ligero barrido que incide en el dinamismo vivo de la escena. El gesto (boca abierta, ojos entornados) establece el grito como lenguaje diferenciador del Rock \& Roll. Ya no es el arrullo melódico del Crooner adobado con una sonrisa, ni la mirada circunspecta del instrumentista virtuoso, ahora el aullido primigenio y el ritmo telúrico adquieren carta de naturaleza en un léxico distinto destinado a un público diferente.

\footnotetext{
ROGERS, Dave, Rock'n'Roll, London, Routledge, 1982, p. 45.
} 


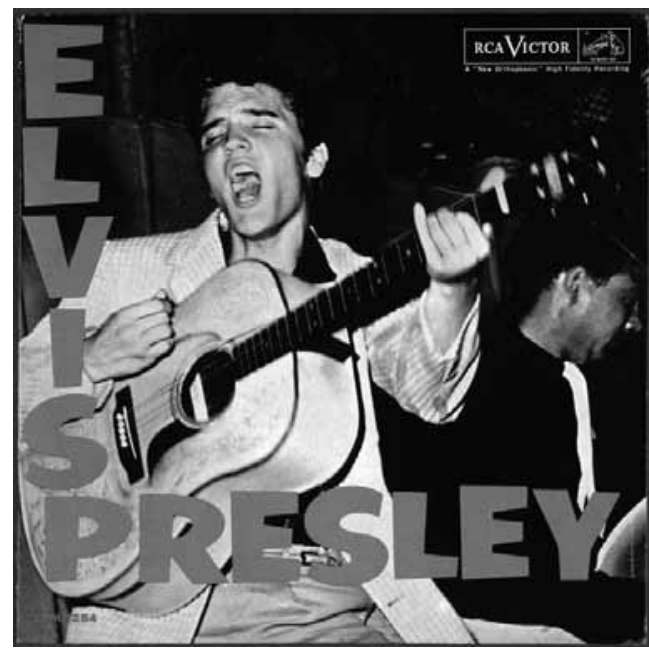

Fig. 1. Elvis Presley, Elvis Presley \# 1 (1956).

Como colofón del diseño de la portada se utilizan dos bandas tipográficas en ángulo recto que ocupan el lateral izquierdo con la palabra ELVIS y el frontal inferior con PRESLEY, la primera troquelada en rosa y la segunda en verde, con tonalidades pastel que producen un gran contraste con la fotografía en blanco y negro. Agitación, grito, guitarra y color serían, en síntesis, los elementos diferenciadores de estas primeras representaciones iconográficas del Rock \& Roll.

Grito, dinamismo y color aparecen también en el LP de presentación de Little Richard, Here's Little Richard (1957). En este caso el cantante y pianista de color se presenta en la portada en un retrato (en blanco y negro) de busto en primer plano sobre un fondo en tonos naranja con degradé bermellón. La tipografía empleada con rotundas letras mayúsculas equilibra la composición con el rostro a la izquierda y el título del disco enfrentado, a la derecha. Nuevamente es el gesto del intérprete el que atrae la mirada, los ojos entornados y la mueca exagerada, el grito con toda la boca abierta y el muestrario dental producen un impacto instantáneo; la ilusión del aullido primigenio, la llamada ineludible del ritmo.

Es posible citar otras portadas del periodo primitivo del Rock \& Roll que abundan en estos mismos detalles recurrentes. After School Session With Chuck Berry (1958), publicado por el sello Chess de Chicago, aporta ese toque personal dentro de los parámetros ya vistos. La carátula utiliza una fotografía de cuerpo entero del guitarrista y cantante sobre fondo infinito sombreado (reflejo de los sets utilizados en los programas de televisión) en la que Chuck Berry aparece en el momento de acometer uno de sus solos incendiarios. La expresión es electrizante; es una instantánea que capta el impulso, no lo congela sino que facilita la comprensión dinámica gracias a la posición de los hombros, la expresión de los ojos y la boca (otra vez abierta) junto a la postura forzada de brazos y piernas. La fotografía es bidimensional pero muestra toda la energía concentrada y el dinamismo rítmico del Rock \& Roll.

Gene Vincent había lanzado una onomatopeya ininteligible, Be-Bop-A-Lula, como un desafío al canon estandarizado de las canciones de amor al uso en la que los nombres de mujer, Carol, Linda, Lucille o María, establecían la norma. Con una pose frágil, distante y ensimismada Vincent se mostraba como una rara avis dentro de los círculos del Rock \& Roll. No obstante, desde la portada de su LP, Gene Vincent Rocks! And The Blue Caps Roll (1958), volvemos a encontrar las constantes iconográficas ya referidas. La instantánea, en este caso en color, muestra un primer 
plano de Gene Vincent en el que se atisba parte del mástil de su guitarra (también ligeramente barrido). Se repiten los rasgos expresivos; ojos cerrados y boca entreabierta; en definitiva, una síntesis visual del dinamismo propio del género.

\section{Beat Británico}

Con la determinante irrupción de un conjunto como The Beatles en los años iniciales de la década de los sesenta el carácter de la música popular británica ejecuta un cambio drástico; pasa de ser una mera imitación de los ídolos norteamericanos para situarse en el epicentro del nuevo pop. Donde antes aparecía un solista más o menos procaz ahora se presenta un conjunto con varios miembros dotados de chispa individual, actitudes nuevas y poses distintivas.

Se puede afirmar categóricamente que The Beatles sustentan la columna vertebral de la iconografía del Rock durante la mayor parte de los años sesenta. Ellos crean un universo audiovisual que nace, crece, se desarrolla e incluso decae tras su separación definitiva en 1970. Al calor de sus éxitos se produce un aluvión de ideas nuevas, conceptos arriesgados y propuestas sin precedentes que alimentan la gestación de otros conjuntos similares, no sólo en el mundo anglosajón sino en todo el ámbito occidental.

Su carta de presentación discográfica en el mercado mundial se confirmó a través de su segundo álbum, With The Beatles (1964) (fig. 2). La portada está presidida por una fotografía en blanco y negro firmada por Robert Freeman en la que el dramatismo lumínico cobra expresividad a través de un eficaz claroscuro. Una explícita seriedad en la pose pretende elevar la categoría musical; ya no es el grito primitivo del Rock \& Roll, estamos ante la proyección visual de una nueva concepción pop en la que imagen y música se complementan y confieren al formato LP un estatus icónico superior. Como observa el propio Freeman se trataba de una apropiación estética más cercana a las portadas de los discos de $\mathrm{Jazz}^{4}$. Los integrantes del grupo, ataviados con suéters negros de cuello vuelto, muestran únicamente la mitad derecha de sus rostros delineados bajo

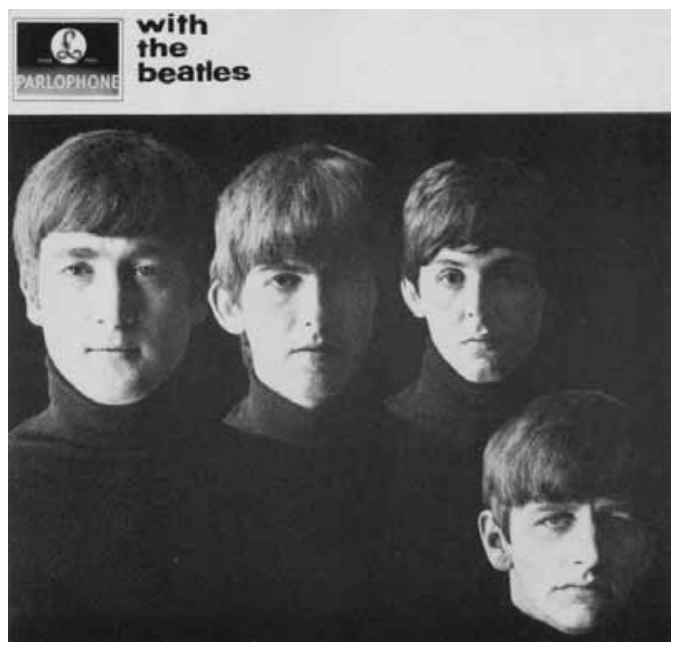

Fig. 2. The Beatles, With The Beatles (1963).

\footnotetext{
4 FREEMAN, Robert, The Beatles, a private view, New York, Ballard Press, 1990, p. 56.
} 
una potente fuente lumínica. Al no caber longitudinalmente los cuatro bustos la composición se resuelve en diagonal, entre el rostro del batería, Ringo Starr, que emerge en el vértice inferior derecho, y el logotipo de la compañía discográfica, Parlophone, junto al título del disco, With The Beatles, que se sitúan en el vértice superior izquierdo.

En la seriedad de los rostros, el tratamiento de luces y sombras, la uniformidad premeditada y hasta en los peinados (se pasa del tupé a la melena a lo paje) radican las novedades del léxico visual de esta portada. Robert Freeman (1941), un joven fotógrafo desconocido entonces, adquirirá fama internacional a partir de este momento y realizará consecutivamente las cuatro fotografías de portada de los siguientes LP's del grupo: A Hard Day's Night (1964), Beatles For Sale (1964), Help (1965) y Rubber Soul (1965).

Tras el éxito incuestionable de The Beatles aflora en Inglaterra todo un elenco de grupos que se venían gestando desde los inicios de la década. Son la espoleta de lo que se vino en llamar "The British Invasion": un periplo musical de ida y vuelta en el que viejos ritmos y melodías del Blues, el Rythm \& Blues y el Rock \& Roll habían sido inicialmente importados desde los Estados Unidos por jóvenes ingleses ansiosos por mixtificar esas músicas aderezándolas ahora con su novedosa impronta visual. The Rolling Stones, The Animals, The Who, The Kinks, The Small Faces o The Yardbirds, entre otros, formaron la vanguardia de esa invasion. En un principio podrían parecer un simple remedo de las actitudes y poses del cuarteto de Liverpool pero finalmente cada uno de ellos logra en poco tiempo definir su personalidad y terminan por enriquecer el panorama de la música pop de esos años. En el aspecto iconográfico podemos citar, a modo de ejemplo, a The Rolling Stones. Su álbum December's Children (1965) sigue empleando la fotografía del conjunto como base, aunque en este caso la toma no se efectúa bajos las condiciones estables de un estudio sino que se lleva a cabo en plena calle en un deseo de conectar al grupo con su audiencia, tratando de otorgarle un halo de autenticidad. Aquí el retrato está firmado por Gered Mankowitz (1946) y utiliza dos fragmentos de un contenedor de obra para enjaular a los cinco componentes del grupo que, comprimidos en un espacio irregular, desafían al espectador a través del objetivo de la cámara que se sitúa en un plano contrapicado ${ }^{5}$. Nuevamente el blanco y negro transmite un dramatismo del que carecería una toma similar en color. En este caso el juego de luces y sombras y la granulosidad de la película acentúan la hosquedad de unos rostros que reciben una luz tamizada, típicamente londinense. Mankowitz, al igual que Robert Freeman con The Beatles, adquirirá gran fama amplificada por el éxito mundial de sus clientes y será su fotógrafo oficial hasta 1968.

MANKOWITZ, Gered, Satisfaction. The Rolling Stones photographs of Gered Mankowitz, London, Sidgwick \& Jackson, 1984, p. 54. 


\section{Psicodelia}

Inmediatamente después del periodo efervescente de los primeros años sesenta y tras el empuje beatlemaníaco se produce una evolución, tanto en lo estrictamente musical como en lo icónico. Así se añaden -en lo musical- elementos tomados de estilos diversos; blues, folk, jazz, clásica, electrónica, etc., también las innovaciones técnicas permiten un mayor grado de experimentación en los estudios de grabación. Otro factor reseñable es el desarrollo argumental en los textos de las canciones, hasta ahora relacionados con inquietudes juveniles elementales, amor, sexo encubierto o subculturas diversas. La irrupción internacional de un músico como Bob Dylan llevará pareja esa transformación: desde sus comienzos en 1962, en los que las letras de contenido social se acompañan de una escueta guitarra acústica, dentro de la ortodoxia Folk, hasta la explosión del Rock Ácido, con guitarra eléctrica, bajo y batería en 1965 y con la inclusión de textos trufados de imaginería compleja, alambicada y surrealista.

Otro de los ingredientes que sirve para potenciar esa interacción audiovisual lo constituye el propio formato LP que a partir de 1966 se presenta como el medio de expresión del nuevo género: el Rock. Se pasa de la colección de canciones a trabajos conceptuales en los que los temas se alargan, se funden y hasta se encadenan sin solución de continuidad.

No se debe ignorar la influencia decisiva de las drogas y su expansión creciente durante el segundo lustro de los años sesenta. Primero los derivados del cannabis (marihuana y hachís) ya utilizados en los círculos Hipster y Beatnik de los años cuarenta y cincuenta y a continuación la dietilamida del ácido lisérgico -LSD- potenciadora de la capacidad sinestésica mediante la cual música y colores, tonos sonoros y cromáticos se confunden y amplifican ${ }^{6}$.

Nuevamente es obligado volver a The Beatles para encontrar el referente paradigmático de la psicodelia inglesa: su LP Sgt. Peppers Lonely Hearts Club Band (1967) (fig. 3). El concepto de la portada corresponde al pintor británico Peter Blake (1932) en colaboración con su esposa Jan Haworth. En un collage a tamaño natural, fotografiado por Michael Cooper, Blake y Haworth, bajo los auspicios de Paul McCartney $^{7}$, presentan un heterogéneo grupo de figuras recortadas y ensambladas sobre siluetas de madera. Son 73 personajes junto a otros 14 artefactos diversos que se entremezclan en un desvarío inaudito y sin precedentes para una carátula discográfica. Los propios Beatles en cera, cedidos por el Museo de Madame Tussaud, asisten impertérritos a la presentación colorista de sus réplicas de carne y hueso. Un abigarrado grupo de figuras se solapan al fondo dando lugar a un auditorio imposible: Marlon Brando junto a Oscar Wilde, Fred Astaire al lado de C. G. Jung o

\footnotetext{
6 Vid. HOFFMANN, Albert, La historia del L.S.D, Barcelona, Gedisa, 2006.

RUDD, Natalie, Peter Blake, London, Tate Publishing, 2003, p. 49.
} 


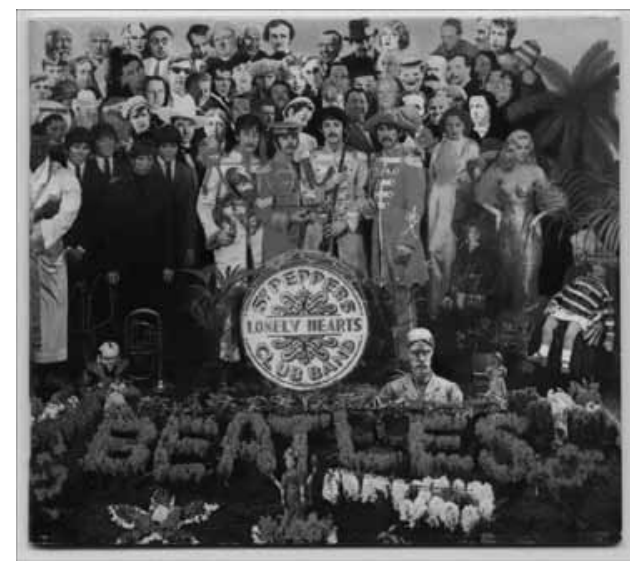

Fig. 3. The Beatles, Sgt. Peppers Lonely Hearts Club Band (1967).

Karlheinz Stockhausen entre Mae West y Aubrey Beardsley. El título del disco queda enmarcado dentro de un elemento real de la parafernalia fotográfica, ya no es un añadido tipográfico postizo, ahora forma parte de la realidad visual del conjunto. Aparecen también una serie de guiños a otros artistas afines -Bob Dylan y The Rolling Stones- y también motivos florales, un televisor portátil, bustos, idolillos hindúes y otros artilugios. Un pastiche pop que apela a la desbordante creatividad que se desprende de la propia música; una colección de canciones amalgamadas con especias exóticas que abren un novedoso horizonte a lo conocido hasta el momento; efectos de sonido, recursos electrónicos, armonías orientales, reminiscencias barrocas, folklóricas y hasta del Music Hall. La portada refleja esa complejidad caleidoscópica y la extravagancia psicodélica de la música grabada en sus surcos.

En este contexto cabe citar algunas portadas que participan de ese sentido psicodélico, de esa comunión sinestésica entre música e imagen. En Inglaterra, Klaus Voorman ya había diseñado Revolver (1966) para The Beatles, en lo que se considera un precedente de Sgt. Peppers. Mucho más psicodélica en sentido estricto es la que creó para el primer LP de The Bee Gees; The Bee Gees 1st. (1967). Y ya absolutamente paradigmáticas serían las del grupo folk The Incredible String Band, The 5000 Spirits Or The Layers Of The Onion (1967), o la del trío británico Cream, Disraeli Gears (1967), diseñada por el australiano Martín Sharp, en la que el paroxismo de los tonos fluorescentes parece que engulle a los componentes del grupo. El autor crea un universo lisérgico donde no hay espacios de sosiego para el ojo del espectador. El color saturado configura un horror vacui de elementos que vibran al compás de la música y que se revitalizan al surtir efecto la dosis justa de LSD.

\section{Rock Sinfónico}

Con el fin de la década de los sesenta el formato LP se impone con rotundidad. Mientras el primitivo Rock \& Roll queda obsoleto por su puerilidad elemental ahora el Rock pretende alcanzar la categoría artística que se le negaba a aquél. El Rock como género en los primeros años setenta se nutre de diversas influencias y produce otros subgéneros: Blues Rock, Hard Rock, Jazz Rock o Latin Rock. Son híbridos y contaminaciones que enriquecen el producto final pero también, en cierto modo, son manifestaciones de un agotamiento estilístico que desembocará 
a mediados de la década en el Punk. Uno de esos subgéneros que se abre paso es el denominado Rock Sinfónico (también llamado Rock Progresivo), con largos desarrollos instrumentales cuyo formato ideal resulta el LP, incluso el doble y hasta el triple LP. La ilustración figurativa gana terreno sobre la fotografía del artista. Las portadas incorporan todo tipo de extravagancias: piezas añadidas, recortes, encartes movibles, objetos adheridos y hasta se alteran los tradicionales formatos cuadrados en aras de la creatividad.

El grupo británico King Crimson fue uno de los pioneros en esa mutación del Rock psicodélico hacia la complejidad orquestal del Rock Sinfónico. Su primer trabajo en formato LP, In The Court Of The Crimson King (1969) presenta muchas de las novedades gráficas que sirven como invariantes del estilo. El rostro angustiado en primerísimo plano que ocupa la portada doble del álbum pretende transmitir el desconcierto reinante, la angustia generacional y la sensación de vacío y agotamiento tras los excesos de la "década prodigiosa". Una premonición apocalíptica de la esquizofrenia del hombre del siglo XXI (como rezaba el título del tema que abría el disco). El arte final, realizado en acuarela y con predominio de tonos púrpura ocupa -a sangre- la superficie total de la carátula doble. No hay nombre de grupo ni título, sólo la expresión aullante y dental del rostro desencajado.

Otro ejemplo de portada conceptual que pretende una visualización de las texturas del Rock Sinfónico se encuentra en Brain Salad Surgery (1973), del trío británico Emerson, Lake \& Palmer. Aquí se recurre al concurso de un artista emergente, el suizo H.R. Giger (1940) (luego reconocido por su trabajo en la creación del monstruo extraterrestre en la película Alien (1979), de Ridley Scott). Giger aportó su personal aproximación a la técnica del aerógrafo para presentar una criatura sideral en la órbita de una estética biomecánica con reminiscencias de Piranesi y a medio camino entre la ciencia-ficción y la taxidermia. En este caso la portada presentaba el rostro femenino en primer plano, con la peculiaridad de contar con un troquel circular que enmascaraba parcialmente la figura. Nuevamente toda la información tipográfica se ubicaba en el interior y así la carátula adquiría un estatus de obra en sí misma, de concepto visual asociado a la música de sintetizadores, bajo y batería que contenían sus surcos.

\section{Glam Rock}

Paralelamente al desarrollo del Rock Sinfónico toma cuerpo otro subgénero en el que el virtuosismo y la trascendencia son sustituidos por una serie de propuestas músico-visuales más cercanas al espíritu original del Rock \& Roll. El Glam Rock se presenta envuelto en los brillos de una presentación glamourosa (de ahí su acepción); un exceso de maquillaje que trata de ocultar el verdadero aspecto de una rebeldía ajada. Ahora cobra importancia el oropel, el fulgor del satén, el iridiscente reflejo de las lentejuelas y las plumas de marabú. Los músicos llegan envueltos en pieles y cueros, elevándose del escenario sobre zapatos de plataforma. La música 
abunda en la recuperación rocanrolera: ritmos cuadrados, repetitivos, bailables, con melodías untuosas e instrumentación convencional. Es un revival espeso y lúbrico.

La ambigüedad sexual es otro de los referentes iconográficos que definen la tendencia, con una presentación claramente andrógina o veladamente invertida. Las drogas asociadas ya no procuran la expansión sensorial sino que se emplean para subir y bajar en el tobogán psicótico; cocaína en el ascenso y heroína como anestesia de una realidad dura. Mientras el Rock Sinfónico seguía un camino expansivo, el Glam Rock propone la supervivencia indolente de la acentuada crisis de los primeros años setenta.

David Bowie es quizá el músico que mejor encarna esa decadencia asumida por el Rock en este periodo. Como botón de muestra se puede analizar la portada de su LP, Pinups (1973) (fig. 4). En este contexto vuelve a ser fundamental la presen-

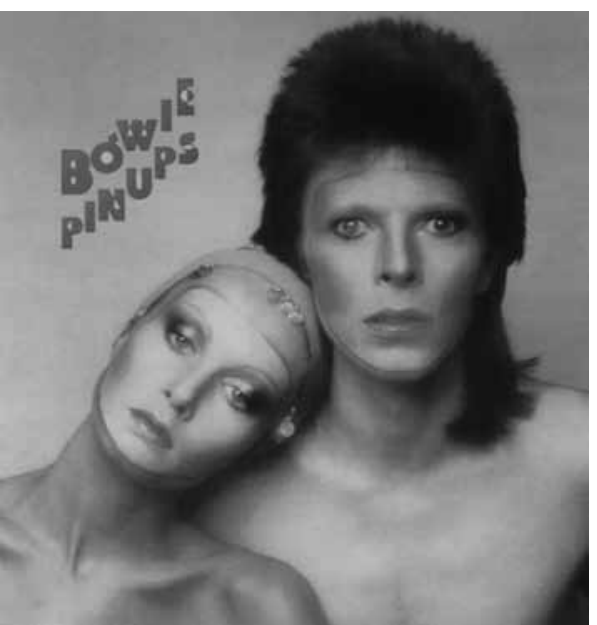

Fig. 4. David Bowie, Pinups (1973). cia física del artista en la carátula, con sus atributos icónicos y tipográficos, su nombre y el de la obra. La calidad fotográfica se pone de manifiesto a través de un depurado retrato en color (obra de Justin De Villeneuve, a la sazón fotógrafo de Vogue y Harper's Bazaar). En una pulcra composición sobre fondo azul celeste aparece Bowie en primer plano acompañado por uno de los personajes clave del "Swinging London" -la modelo Twiggy-. Ambos rostros riman en cuanto a tonalidad y expresión. Los torsos desnudos se empastan con el fondo mientras el maquillaje (acreditado a Pierre Laroche) se erige en protagonista gráfico, confiriendo a las dos figuras unos rasgos alienígenas. Destaca asimismo el esculpido corte de pelo -Kabuki- y el tono naranja del tinte capilar, ciertamente inusual en la presentación cosmética masculina de la época. La tipografía en rojo-amarillo (Ray Campbell) reverbera sobre el fondo con unos caracteres retrofuturistas, entre lo sideral y lo camp.

\section{Punk}

Es una constante que el Rock como género ha adolecido de la inestabilidad propia de los movimientos efímeros, de una suerte de fugacidad que avala las tesis de Dorfles expuestas en Símbolo, Comunicación y Consumo $^{8}$, entendiendo este úl-

\footnotetext{
8 Vid. DORFLES, Gillo, Símbolo, Comunicación y Consumo, Barcelona, Lumen, 1975.
} 
timo concepto como el desgaste que ofrece un producto tras su exposición pública a través de los medios de comunicación de masas.

El Rock en los primeros años setenta vive instalado en las inercias de una decadencia asumida. Por un lado, como hemos referido, se ha producido una evolución cualitativa encarnada en el Rock Sinfónico que en poco tiempo satura formas y contenidos de elementos vacuos -virtuosismo- y decora los paisajes icónicos a base de excursiones oníricas. Por otro, el Glam Rock ofrece una imagen decadente revisando logros pasados como el Rock \& Roll, pero presentándolos bajo envoltorios teatrales y afectados. El Punk surge como rechazo generacional hacia todo esto. Frente a la indolencia y fastuosidad de los "dinosaurios del Rock" de los años setenta (Pink Floyd, Led Zeppelin, Rolling Stones), el Punk opone la opacidad de lo sucio. Su imaginería es eminentemente urbana alejada del bucólico hippismo sinfónico y entregada a la exaltación del detritus, la violencia y el despojo. Ante los destellos satinados del vestuario Glam propone el color negro como bandera. Contra la pretenciosidad hueca del Rock Sinfónico proclama la inmediatez elemental de la canción pop: tres minutos de condensación rítmica y un escueto telegrama vocal por todo texto.

El prototipo de esa explosión Punk de la primera hora no es otro que el grupo inglés Sex Pistols, cuya efímera duración -un año- sólo se entiende desde la propia proclama punk: No Future!. En el caso de Sex Pistols va resultar más trascendente la impronta publicitaria que su propia música y con ello se reafirman las fuentes situacionistas propuestas diez años antes por Guy Debord: "La victoria será para aquellos que sepan crear un desorden sin desearlo"".

Su álbum de presentación Never Mind The Bollocks (1977) (fig. 5) muestra la radical cesura iconográfica con lo visto hasta el momento. En esa evolución cronológica, desde el simple retrato del artista de los años cincuenta, pasando por la exuberante creatividad de las portadas de los años sesenta, se llega ahora al mensaje crudo, a la proclama grosera: iQué cojones importa, aqui están los Sex Pistols! Sobre un fondo amarillo puro se plantea esta frase utilizando una tipografía de "rescate", con letras recortadas de tabloide inglés. Debajo, sobre una banda fucsia perfilada a tijeretazos se troquelan los desiguales tipos que conforman el nombre del grupo. El autor del diseño es Jamie Reid (1947), que ya había colaborado en la creación de la revista The Suburban Press, en 1970; interpretación anglosajona de la agitación producida por la Internacional Situacionista y los acontecimientos del Mayo francés. Inspirado en las proclamas garabateadas en los muros de París y en los pasquines y carteles facturados de un modo clandestino por los colectivos franceses, Reid crea toda una tipología del punk: fotocopias, letras recortadas, am-

9 Vid. DEBORD, Guy, Internationale Situationiste, 1958-1969, Paris, Champ Libre, 1975.

En español se puede consultar PERNIOLA, Mario, Los Situacionistas. Historia crítica de la última vanguardia del siglo XX. Madrid, Acuarela, 2007. Y como texto de referencia en la relación entre Punk Rock y la Internacional Situacionista es muy recomendable MARCUS, Greil, Rastros de carmín, Barcelona, Anagrama, 1993. 


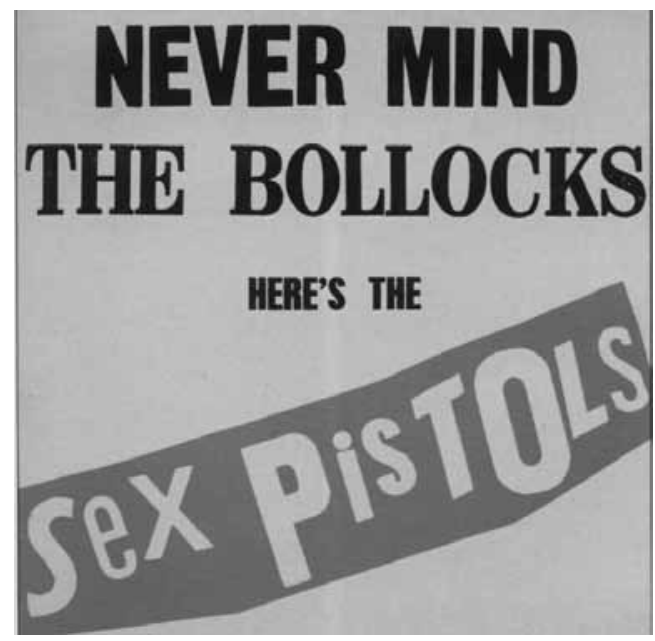

Fig. 5. Sex Pistols, Never Mind The Bollocks - Here's The Sex Pistols (1977). pliaciones tramadas de fotografías de prensa, alto contraste, colores saturados así como un despliegue de atributos relacionados: imperdibles, clips, pinzas, parafernalia nazi, látex, PVC, tachuelas, cuero negro y botas Doc Martens.

\section{New Wave}

Como una prolongación temporal y efímera del Punk se sucede el fenómeno audiovisual conocido como New Wave. Tras aquel estallido iconoclasta las aguas del Rock comienzan a amansarse con un ímpetu renovado. Se impone el color, la uniformidad y una vuelta a la melodía pop. La canción de tres minutos con estructura canónica -estrofas y estribillo- vuelve a marcar la pauta. Ahora la industria discográfica se recompone y donde hace dos años había sellos independientes y autogestión, ahora se ofrecen productos elaborados. El videoclip, junto a las portadas de discos y las cuatricromías de las revistas especializadas van a articular gran parte del discurso icónico-musical de la nueva década. Si en los años sesenta y setenta los medios de comunicación ofrecían los estímulos audiovisuales del Rock con cierta apatía ahora la industria asimila las tendencias subterráneas, las empaqueta y las lanza a un mercado ávido de novedades.

Entre los caracteres recurrentes del periodo se aprecia un gusto por las texturas sintéticas y lo artificial. Las tipografías adquieren rasgos geométricos deudores del constructivismo ruso y muchos diseños de portadas encuentran inspiración en elementos dispersos tomados al azar del Futurismo, Dada, Neoplasticismo, Bauhaus, Op Art y Pop Art. Se podría afirmar que la New Wave, tanto en lo musical como en lo iconográfico, es una de las más genuinas representaciones de la postmodernidad, entendiendo como tal la utilización y mixtura de un variado cocktail de influencias que mana de fuentes diversas. Un pastiche audiovisual que marca el principio del fin del Rock como contracultura y lo instala cómodamente en el escenario global, comercial, masivo y decadente en el que desde ese momento se encuentra sumido. A continuación se abre un periodo acomodaticio, de grandes estrellas encapsuladas en su éxito, de una preeminencia abrumadora de la imagen del artista asociada a la televisión y hasta la propia defunción del formato LP que es sustituido por el Compact Disc (CD) en 1982. La otrora superficie satinada de $33 \times 33 \mathrm{~cm}$. se ve reducida ahora a $14 \times 12 \mathrm{~cm}$. con el reclamo de una aparente calidad de sonido, libre de ruidos parásitos pero cercenadora de las frecuencias más profundas tan caras al Rock. Tiempos cambiantes, otras actitudes. Nuevos formatos para un género que 
sobrevive hasta llegar al siglo XXI con el ímpetu renovado pero con el lastre de una sociedad global y caprichosa. Es la confirmación audiovisual de esa posmodernidad mostrada como construcción/deconstrucción, bebiendo en fuentes pretéritas pero logrando facturar productos novedosos, híbridos pero válidos; en definitiva, consumibles. Ya no es ni siquiera necesaria la presencia del artista, ahora se ofrece un abanico inmenso de posibilidades; fotografía, ilustración, reelaboración pictórica, trazos geométricos o simples texturas coloreadas. La norma es la antinorma y la fórmula válida el refrito. El devenir de la década de los ochenta se barroquiza hasta llegar al empalago. La opulencia de las estrellas, su teatralidad, y la progresiva masificación las convierte en cautivas de su propio éxito y así surgirán en los años recientes nuevas reacciones, ramificaciones, contagios, híbridos y monstruos: Rap, Grunge, Hip-Hop, Trip-Hop, Afrobeat, Industrial, World, Gothic, Metal, Trash, Hardcore, Brit Pop, Post Rock, Americana, Electro, Anti Folk, etc., etc., etc., todos con su bagaje iconográfico asociado, apoyados en una panoplia de imágenes que asoman desde medios fulgurantes y efímeros. Un despliegue audiovisual que inunda, sacia y satura los ansiosos sentidos de los consumidores del siglo XXI. 